\title{
Are Growth Led Financing Decisions Causing Insolvency in Listed Firms of Pakistan?
}

\author{
Rana Yassir Hussain* \\ Xuezhou Wen ${ }^{* *}$ \\ Rehan Sohail Butt**** \\ Haroon Hussain \\ Sikandar Ali Qalati \\ Irfan Abbas ${ }^{* * * * * *}$
}

\begin{abstract}
We examine the relationship between growth opportunities and insolvency risk in a mediating framework through financing decisions for 330 listed firms on the Pakistan Stock Exchange (PSX) This study covers a data period of five years ranging from 2013 to 2017. Financing decisions used in this study involve capital structure decision and debt maturity decision. We applied robust clustered panel OLS regression to the data and found a negative relationship between growth opportunities and insolvency risk in all samples consisting of overall, large and small firms. Growth opportunities have a negative impact on the capital structure, but debt maturity was influenced positively. Financing decisions influenced the insolvency risk positively. We used Baron and Kenny's (1986) approach to detect the intervening effects of financing decisions. Further, Sobel's test used to check the significance of mediation. Partial mediation was found for the debt maturity ratio in the large and overall sample of firms. However, the capital structure did not mediate the relationship between growth opportunities and insolvency risk in this study.
\end{abstract}

Keywords: Growth Opportunities; Financing Decisions; Insolvency Risk

JEL Classification: G30, G32

\footnotetext{
${ }^{*}$ Rana Yassir Hussain is at Jiangsu University Zhenjiang, Jiangsu China.

** Xuezhou Wen is at School of Management, Jiangsu University / School of Business, Jiangnan University, Jiangsu Province, China

${ }^{* * * *}$ Rehan Sohail Butt is at School of Management Jiangsu University, Jiangsu China.

${ }^{* * * * *}$ Haroon Hussain is at Noon Business School, University of Sargodha, Pakistan.

****** Sikandar Ali Qalati is at School of Management Jiangsu University, Jiangsu China.

${ }^{* * * * * * *}$ Irfan Abbas is at Key Laboratory of Modern Agriculture Equipment \& Technology, Ministry of Education, Jiangsu University, Jiangsu China.
} 


\section{Introduction}

Firm failure is a growing phenomenon in today's competitive environment, especially for new firms trying to grow (Mellahi \& Wilkinson, 2004; Sun, Li, Huang, \& He, 2014; Lukason \& Laitinen, 2016). Previous research confined to the external factors that hinder the growth of young and small enterprises. There is a lack of literature that focuses on the contribution of internal processes and decisions, which may put the firms on the right track or opposite notes cause ultimate failure. Firms that have growth potential may require more finances as compared to mature firms. Financing comes with the cost that includes agency cost, financial cost and finally bankruptcy costs if not handled properly. The importance of financing decisions is well documented in corporate finance literature. Many factors lead the decision-makers to opt for a particular financing policy, but this study emphasizes the impact of growth opportunities on insolvency risk influenced through financing decisions taken. There is diversity in financing resources raised, and the extent to which a particular resource preferred over the other is also diverse. For example, the choice between equity and debt is a first option (if an exclusive choice made) and how much to invest in equity and debt termed as the capital structure is another choice (if both sources used). Similarly, if the debt used in the capital structure, its maturity is another crucial decision as a part of the financing decision. The cost of financing is another critical aspect that can be placed under this umbrella but mostly regarded as a determinant of capital structure and debt structure rather than being a part of it. However, the higher cost of financing might also contribute to the higher insolvency risk. Rationality seems to be in less risky situations, but the literature suggests that the managers sometimes take aggressive positions and earn abnormal profits. Thus, risk-taking is not always thought to be evil. Risk cannot still be regarded as a hazard but also an opportunity to prosper and grow. According to Kim (2011), firms with more foreign investors take more risk, and such risk has a positive relationship with growth opportunities. Therefore, growth opportunities can be regarded as determinants of risk levels attained by any organization, but an organization can not avail of any opportunity without proper resources needed to indulge in any venture.

Resource dependency theory postulates that managers need to deploy their resources in such a way that enables them to reconfigure their resources to take advantage of the numerous opportunities available. Mateev \& Anastasov (2010), argued that an organization's growth potentials have a relationship to firm size and are also associated with its financial mix. Therefore, what resources, whether financial or non-financial secure vital positions in the hands of management. The pecking order theory suggests that organizations follow a distinct pattern in the utilization of financial resources. The proponents of this theory state that organizations prefer funds in an order in which retained earnings, debt, and equity secure first, second, and third ranks, respectively. All of these options have varied economic consequences. For 
example, the debt is thought to be riskier as compared to the other two options, but it is also a tool to discipline the managers at the same time. The availability of retained profits is an ideal situation where organizations have enough resources of their own. Equity is the most undesirable option as it involves high flotation cost and also the controlling power of the current shareholder lost with every new seasoned issue. Organizations follow the trade-off theory that postulates that managers tend to strike a balance between debt and equity options termed as capital structure. Debt is a preferable option also due to the tax advantage associated as compared to the equity.

Growing firms require more external resources due to the growth potentials. Growing organizations face constraints while accessing the external equity, but if somehow they manage to get it, the terms of such financing are not reasonable as they will be required to pay more in the shape of interests and other associated costs. The chances of failure of immature firms are also comparatively quite high. So, the growth possibility of small and medium companies is devastating (Huyghebaert \& Van de Gucht, 2007). Durinck, Laveren, \& Lybaert (1997), concluded that firms that experience rapid growth exploit more borrowed money as compared to equity. Their sample consisted of small and medium-sized enterprises in Belgium. This study supports the principles of the pecking order theory. Previous research supports a positive link between firm growth and debt financing (Heshmati, 2001; Honjo \& Harada, 2006). At the same time, earlier studies like (Frank \& Goyal, 2009) support a negative relationship between debt and an organization's growth opportunities. Such studies argument that more growth opportunities leave limited cash resources that makes them unable to get a loan because they have less money to service the debt. Similarly, Myers (1977), raised an argument that firms with risky debt can reject the projects with positive net present values; this situation leads them to move towards equity to sustain their growth. It causes a negative relationship between growth opportunities and financial leverage. Autio, Sapienza, \& Almeida (2000), claimed that there is a negative association between growth opportunities and age. Researchers like (Frank \& Goyal, 2003; Myers, 1984), argue that small firms at a young age do not possess enough assets to be declared as collateral against debt and also face the problem of risky indebtedness due to much less information symmetry. Moreover, Leary and Roberts (2014), stress that financing decision is an internal decision taken by the firm's management and should be treated as endogenous. However, firms can have similar financing structures if they tend to copy similar patterns. Mature firms have sufficient resources of their own and need to retain the market share and have lesser growth prospects. The life cycle theory divides the life of an organization into various life stages. Each stage has a varied necessity of resources. It means a growing firm should require more financial resources, and at the same time, the grown-up firm can get loans with comparative ease, but they might not need it. Therefore, due to this constrained external financial environment, new firms usually rely on equity or private loans to excel. This situation should oppose the common knowledge based 
on the pecking order theory, or we may propose that there can be a reversal of the pecking order depending upon the life stages of an organization. Therefore, what effect growth opportunities have on the insolvency risk is noticeable and is also the focus of this research in the presence of financial decisions taken. Previous research is mostly confined to study this relationship in financial firms and that too, primarily for banks. There is little evidence of empirical testing in non-financial firms. We suggest that this situation may affect all the corporations as financial management is integral in today's corporate governance scenario, and firm failures are also more consistent in other sectors even in the absence of a financial crisis. Whereas, financial institutions face and trigger such disliked outcomes mostly in the adverse macro-financial environment. Moreover, financial institutions are protected by various safety nets and insurance provisions that may lead managers to gulp more risk, but non-financial managers could be behaving differently, but it needs to be tested empirically and more frequently.

Firms with growth opportunities require more financing as compared to the ones with lesser chances. Managers look towards borrowed finance after consuming owned resources in such situations. Borrowed capital is also attractive because it has less related costs like floatation cost, agency cost, and also tax benefits. However, debt is thought to be riskier and can cause bankruptcy if not appropriately managed but still preferred over equity as posited by pecking order theory. Evidence on the relation between growth and debt is mixed. Many studies prove this relationship to be positive, like (Pandey, 2001; Chen \& Zhao, 2006). There is also enough evidence that supports a negative relationship between growth opportunities and financial leverage (Goyal, Lehn, \& Rcic, 2002; Billet, King, \& Mauer, 2007). Decisions regarding leverage also involve the choice to choose between short term and long term debt. To tackle the issues of a lower level of investment and asset substitution, organizations with more profitable opportunities to grow will tend to reduce the maturity of their debt structure (Barclay \& Smith, 1995; Cuñat, 1999). This issue becomes more acute for firms that have utilized their internal resources and are now targeting external resources to keep-up with their projects. Researchers like Akerlof (1970) Leland \& Pyle (1977), Ross (1977), and Yosha (1995), are the supporters of signaling theory and on its relevance, support the argument that profitable organizations, having growth prospects and good credit standing will opt for short term financing. They may also enjoy the benefits of less associated costs as compared to the organizations experiencing financial crunch. This situation can pose rollover risk as the firm needs to refinance its growth after regular intervals and cause an illiquidity problem supported by liquidity theory. Financially stable organizations can cope with the short term debt without any increment in insolvency risk because they have better information symmetry and are in a better position to easily roll on their short term financing (Flannery, 1986; Stohs \& Mauer, 1996). 


\section{Literature Review and Hypothesis Development}

\section{Growth Opportunities and Insolvency Risk}

Growth opportunities cannot be viewed without taking into account threats and associated risks. Such uncertainty is varied across segments, and the firms which focus diversification in their products or the business segments have more growth opportunities as compared the concentrated organizations. Such an organization also suffers less as to the risk because it also gets diversified as compared to the focused firm. If we rank those opportunities higher that have less associated risk, then the organizations with such opportunities will be well off as compared to their counterparts. Such options contribute significantly to the value of firms (Kester, 1984; Danbolt, Hirst, \& Jones, 2002). Anderson \& Garcia-Feijoo (2006), inferred that investment opportunities have a strong affiliation to future stock returns and the value of the firm. Cao, Simin, and Zhao (2008), also supported the existence of incremental idiosyncratic risk caused by growth opportunities. Berk, Green, \& Naik (1999), discussed that risky growth options could predict firm value. They also captured the heterogeneity already embodied in growth options that leads to varying risk levels. There is also a stream of researchers that support the free cash flow hypothesis (McConnell \& Servaes, 1995; Lang, Ofek, \& Stulz, 1996). This argument facilitates a situation of over investment. Overinvestment leads to the consumption of funds on non-profitable growth opportunities, and underinvestment leads to letting go of profitable opportunities technically regarded as projects with positive NPV (Brealey, Myers, \& Allen, 2008). Both overinvestment and underinvestment are value-destroying and harm firm performance. Previous empirical findings found a negative effect of overinvestment and underinvestment on firm performance Titman, Wei, \& Xie (2004), Yang (2005) and $\mathrm{Fu}(2010)$ regarded this scenario equally devastating for any organization. Information asymmetry and wrong selection are also phenomena that become relevant in the presence of opportunities to grow (Alonso, Lopez, \& Rodriguez, 2005). Amaral (2008), postulated that the firms which follow rapid growth are also the ones that become victims of failure more often. However, it is also true that small firms grow faster as compared to large ones. Elgers and Murray (1982), proved a statistically significant association among growth opportunities, debt, size, and risk. Their data consisted of accounting variables. A study conducted by Fewings (1975), also theoretically witnessed how the growth in organizational profit and profit on shares affects the risk of common shares. There exists a positive relationship between these growth potentials and risks. Skinner \& Sloan (2002), regarded it as a market-wide phenomenon in the sense that growing firms may experience fewer earnings and are under constant pressure to avoid any earning surprise to access quality capital with less cost factor at the same time. Beaver, Kettler, \& Scholes (1970), said that it is because organizations need to represent stable earnings and such efforts to smooth 
earnings may increase a factor of accrual basis because fluctuated earnings can cause more firm-level risk. Gray \& Johnson (2011), studied the impact of growth on stock returns but didn't find any explanation of the associated risk. Similarly, Gomes, Kogan \& $\mathrm{Lu}$ (2003), said that growth opportunities are a risk, and existing assets are not. They noted that growth opportunities usually are exercised by getting loans against the existing.

Various studies support a positive link between growth and risk, but it depends on the life stage an organization is going through (Kim B. , 2011; Akbar, Akbar , Tang, \& Qureshi, 2019; Habib \& Hasan, 2015). Usually, firms at initial stages tend to grow to gain sustainability and shift towards more mature and stable stages. To achieve this milestone, they have to go through various available options to select. If they do not find any opportunities, they will squeeze their existence and hence move towards bankruptcy. It means if an organization in early growth phases does not find suitable growth opportunities within acceptable risk levels will eventually come up as a failure. So, to grow, an organization must have to take risks, which are an associated bundle with growth opportunities. If organizations take calculated risks that are bearable with managed opportunities, the chances of insolvency may reduce. Therefore, one can propose the following hypothesis:

$H_{1}=$ There $i s$ a significant relationship between growth opportunities and insolvency risk.

\section{Growth Opportunities and Financing Decisions}

Organizations with growth potentials enjoy the better market value and also better assets in place, but their expected income streams are delayed. They need finance at present to ensure future income flows. So, they usually tilt towards borrowing to catch up with these growth opportunities (Parsons \& Titman, 2007). Frank \& Goyal, (2009) and Dudley, (2012), on the other hand, say that such firms can easily generate new equity and are considered overvalued firms in the market. Some studies report a nonlinear relationship between growth and external debt (Wu \& Yeung, 2012). They stated that if more impetus is on the assets in place, then firms will usually go for debt and on the contrary, for equity. Two contradictory theories explain this phenomenon. One being the pecking-order theory proposed by Myers (1984), which favors the use of debt over equity while agency cost theory purports an opposite direction in which managers tend to play safe, and such firms are thought to be ownership controlled. Researchers like Chaplinsky \& Niehaus (1990) and Jensen \& Meckling (1976) are the ones that prove a negative relationship between growth opportunities and debt ratio, especially in growing firms. Baral (2004), also suggested high agency costs for growing firms in growing industries and regarded more growth potentials being the reason. 
If we dig more into this relationship, the previous research also detects the relationship between growth opportunities and long term debt and between growth opportunities and the short term debt. Long term debt is thought to be positively associated with growth, whereas short term debt has a negative association. Researchers that support this argument include Abor \& Biekpe (2009). Ahsan, Wang \& Qureshi, (2016), and Alipour, Mohammadi \& Derakhshan (2015) used different proxies for growth opportunities like growth in sales and growth in assets and reported the negative relationship of these proxies with short term, long term, and total debt ratio. Barnea, Haugen \& Senbet (1980), explained a lower level of sensitivity to short term debt as asset value fluctuate slightly in short time horizons which helps managers to tackle asset substitution problem and Carey \& Rosen, (2001) and Chemmanur \& Fulghieri, (1994) inferred that the flexibility of credit terms offered by banks and also the ability to negotiate for debt allows adjusting the maturity of obligations obtained. So, as managers, we can use debt maturity to control agency problems. If the expiry period of debt is more extended than the execution of selected opportunities, such a situation can lead to higher firm value.

Firms with growth opportunities require more financing as compared to the ones with lesser chances. Managers look towards borrowed finance after consuming owned resources in such situations. Borrowed capital is also attractive because it has less related costs like floatation, agency, and even tax benefits. However, debt is thought to be riskier and can cause bankruptcy if not appropriately managed but still preferred over equity as posited by pecking order theory. Evidence on the relation between growth and debt is mixed. Many studies prove this relationship to be positive, like (Modigliani \& Miller, 1958; Pandey, 2001; Chen \& Zhao, 2006). There is also enough evidence that supports a negative relationship between growth opportunities and financial leverage (Myers, 1977; Titman \& Wessels, 1988; Goyal, Lehn, \& Rcic, 2002; Billet, King, \& Mauer, 2007). Decisions regarding leverage also involve the decision to choose between short term and long term debt.

$\mathrm{H}_{2}=$ There is a significant impact of growth opportunities on firm financing decisions.

\section{Financing Decisions and Insolvency Risk}

The research on the relationship between financing decisions and risk is confined to financial organizations, and there is a scarcity of literature that addresses this issue in non-financial firms. Previous research has also established this argument that risk levels are kept in mind while choosing among debt and equity. However, it does not address the post-decision effects that what influence does a particular decision has on the insolvency risk of a corporation. Does it succeed in mitigating or avoiding insolvency risk? A risk at the macroeconomic level leads to an increase in cash reserves (Almeida, Campello, \& Weisbach, 2004; Baum, Caglayan, Stephan, \& Talavera , 
2008), and entrenched managers try to borrow at expensive terms. There is scarce literature that discusses the after-effects of more debt as part of capital structure. Chung, (1989), reported a positive relationship between financial leverage and risk inherited in assets, whereas Hamada (1972), indicate a positive association between risk and debt. Gertler \& Hubbard (1993), reported that the firm-specific risk is controllable, but risk at the macro level is beyond a firm's control while they were trying to detect the association of such risks with financial decisions. Many researchers like Brealey \& Myers (1981), Castanias (1983), and Bradley et al. (1984) proved an inverse relationship between idiosyncratic risk and financial leverage. The organization discourages debt because of its ties with bankruptcy. This phenomenon discussed under the trade-off theory as bankruptcy hypothesis. There is another stream of research that examines this negative relationship as a way to reduce the cost during financial distress. Organizations that are not sure about their future cash flows tend to reduce the proportion of debt to avoid debt-related costs. Myers (1977), findings were opposing these two arguments who instead opted for agency cost hypothesis. He proved a positive relationship between risk and financial leverage, arguing that more debt will help control agency problem as the debt is a tool to discipline the managers. Similar arguments are presented by several other authors like Jaffe \& Westerfield (1987), Kim and Sorensen (1986)(1986), and Chu \& Chiou (1992). Toy, Stonehill, Remmers \& Wright (1974), proved a positive relationship between earning volatility and leverage of firms based in the US, Japan and Norway. Another critical study conducted by Kale, Noe \& Ramirez (1991), examined a negative association among risk and leverage up to an extent but became positive afterward. Heckbarth, Miao, and Morellec, (2006), stated that the use of debt by an organization is dependent upon macroeconomic situation in an economy and termed this relationship as pro-cyclical. Levy and Hennessy (2007), regarded the equity issue as pro-cyclical and claimed that debt levels reduced in adverse macroeconomic conditions. Chen (2010), made his analysis interesting by capturing the discount rates that increase in adverse macroeconomic conditions, which reduce discounted tax benefits and also make future cash flows vaguer, resultantly a reduction in the use of financial leverage.

Debt maturity refers to the use of long term and short term debt in a firm's capital structure. Debt is thought to be risky in comparison to equity, but the debt with shorter maturities can have even more deteriorating effects. It needs refinancing; otherwise, the firm will face illiquidity as proposed by liquidity theory. So the firm faces rollover risk to finance its operations. This situation opposed by agency theory and signaling theory. However, proponents of information asymmetry advocate the use of short term debt (Flannery, 1986; Diamonds, 1991). The sound organizations can obtain the desired debt maturity as they possess better information symmetry. Firms should get long term loans just before their financial health starts deteriorating because it will provide them with resources for more extended periods, which will also inhibit the possible rollover risk faced otherwise. Overload of debt is also a scenario 
in this case, but it can be possible within both debt streams, but it is more severe in case of longterm debt as posited by Moyen (2007). Scherr \& Hulburt (2001), said that the relationship between debt maturity and the risk of default is not monotonic. Further, based on Altman's Z score, they divided the firms into three categories named firms with high, low and medium levels of default probability. They proved that debt maturity for low and high default probability firms is low as compared to firms with medium default probabilities. Titman \& Tsyplakov (2007), and Leland (1994b), said that the short term loan is used to deal with the problem of under-investment, but it increases the chances of default at the time. Diamond \& He (2014), regarded debt with shorter maturities as a reason for under-investment in cases where the obligation expires even before the investment decision. He \& Xiong (2009) and Morris $\&$ Shin (2016), argued that there might arise a problem of illiquidity, and failure of terms with the creditors may cause a higher rollover risk and put firms under distress. Brunnermeier \& Pedersen (2009), Acharya, Gale, \& Yorulmzer (2009) and Shleifer \& Vishny (2009), discussed that such a situation allows the lenders to dictate unfavorable terms on loans. It may include more margins on mortgage loans, which ultimately, in case of failure, can lead to the liquidation of assets. Morris (1976), also discussed that firms might fall short of cash flows if debt maturity is much less as they will fail to generate enough money too early to meet the debt obligations. This situation can also haunt in case of long term debt, but its probability is very low, and it also enables us to get rid of the current rollover risk. In the case of long term debt, the assets may retire before the loan payment date, and may not generate abundant cash flows. That's the reason theoretical discussions favor maturity matching approaches.

$\mathrm{H}_{3}=$ There is a significant impact of financing decisions on insolvency risk.

\section{Mediating Role of Financing Decisions}

Previous literature proves a positive relationship between growth opportunities and leverage decisions (Hamada, 1972; Gertler \& Hubbard, 1993). Firms tend to increase debt in their capital structure to take advantage of the possible investment opportunities, and the use of more debt leads to the increase in the insolvency risk (Castanias, 1983; Bradley, Jarrel, \& Kim , 1984). The debt structure also involves debt maturity. The choice between short term and long term debt is dependent upon the available profitable growth opportunities. Short term debt is considered to hamper the firms more that have less information asymmetry. The timeline of the debt also determines the level of insolvency risk as short term debt causes more risk as compared to the long term debt called rollover risk. Past studies have developed a mediating role of capital structure (Naseem, Lin, Rehman, Ahmad, \& Ali, 2019; Van Essen, Van Oosterhout, \& Carney, 2012; Detthamronga, Chancharata, \& Vithessonthi, 2017; Ramli, Latan, \& Solovida, 2018; Kassim, Ishak, \& Manaf, 2013; Ramli \& Nartea, 
2016; Zhang, Venus, \& Wang, 2012), but there is a lack of research that considers debt maturity along with capital structure as a mediator ( Umrie \& Yuliani, 2014), collectively regarded as a financing decision in a single study. Recently, Naseem et al. (2019), studied the impact of the CEO's personal and organizational attributes on performance by using the data of 179 listed Pakistani firms from 2009 to 2015. Their results proved significant, and also the debt to equity ratio partially mediated this relationship. Similarly, Detthamronga et al. (2017), split his sample firms into small and large sub-samples. He detected the impact of the audit committee on performance in large firms and audit reputation on performance in small firms. Moreover, the relationship between audit committee size and the firm performance had a mediating effect of leverage decisions in large firms. La Rocca (2007), argued that the role of moderation or mediation of capital structure should be considered on the relation between corporate governance and firm's value. Van Essen et al. (2012), reported that the mediating role of the capital structure must be addressed while studying the role of corporate governance. It is meaningless to consider the role of corporate governance especially board characteristics, without analyzing the decisions, mechanisms and processes opted by management that brings variation in performance and other outcomes at the firm level. Firms take leverage decisions to support their financing needs to avail the set of opportunities to grow and prosper. Ramli et al. (2018), did a comparative study on Malaysian and Indonesian firms for a period of 1990-2010. They used PLS-SEM (Partial least squares-structural equation modeling) in their research and detected the mediating effect of leverage in Malaysian firms while studying the impact of asset structure, growth opportunities, tax, liquidity, and interest on firm performance. No such evidence found in Indonesian firms. Kassim et al. (2013), examined the influence of the board process on firm performance with capital structure decisions as a mediator. The presence of the mediating variable helps to explain the impact of board characteristics, including ownership structure and board structure on firm performance. So, the following hypothesis can be drawn:

$\mathrm{H}_{4}=$ Financing decisions have a mediating effect on the relationship between growth opportunities and insolvency risk.

\section{Data Sample and Methodology}

\section{Data sample}

This study includes all non-financial firms listed on the Pakistan Stock Exchange (PSX) subject to the availability of data for five years ranging from 2013 to2017. The data were extracted from the Financial Statement Analysis of non-financial companies published by the State Bank of Pakistan (SBP). Following points are considered for eligibility of firms to include in the sample: 
1. All those firms which had missing values excluded from the sample.

2. Only those firms secured their presence in the sample, which was continuously in operation during the study period.

3. Those firms which had data from the year 2008 included because data for five years before the study period was required to calculate the standard deviation of return on asset.

Based on the criteria defined above and the requirements of data analysis following table includes the complete sample description. The SBP represents the economic groups defined in the table below until the year 2017.

Table 1: Sector-wise Distribution of the Sample with Large and Small Firms

\begin{tabular}{|l|c|c|c|c|c|}
\hline Economic Groups & Total & Dropped & Included & Large & Small \\
\hline 1) Textiles & 136 & 07 & 129 & 48 & 81 \\
\hline 2) Sugar & 30 & 02 & 28 & 20 & 08 \\
\hline 3) Food & 16 & 03 & 13 & 06 & 07 \\
\hline $\begin{array}{l}\text { 4) Chemicals, chemical products and } \\
\text { Pharmaceuticals }\end{array}$ & 43 & 07 & 36 & 19 & 17 \\
\hline 5) Manufacturing & 31 & 04 & 27 & 12 & 15 \\
\hline 6) Mineral products & 9 & 03 & 06 & 03 & 03 \\
\hline 7) Cement & 17 & 00 & 17 & 17 & 00 \\
\hline 8) Motor vehicles, trailers and auto parts & 18 & 00 & 18 & 13 & 05 \\
\hline 9) Fuel \& Energy & 22 & 07 & 15 & 12 & 03 \\
\hline $\begin{array}{l}\text { 10) Information, Communication \& transport } \\
\text { Services }\end{array}$ & 11 & 01 & 10 & 09 & 01 \\
\hline 11) Coke and refined petroleum products & 10 & 01 & 09 & 09 & 00 \\
\hline 12) Paper, paperboard and products & 9 & 01 & 08 & 04 & 04 \\
\hline 13) Electrical machinery and apparatus & 7 & 01 & 06 & 03 & 03 \\
\hline 14) Other services activities & 10 & 02 & 08 & 05 & 03 \\
\hline Total: & 369 & 39 & 330 & 180 & 150 \\
\hline
\end{tabular}

This table shows that textile is the most crucial sector of the PSX which is the major Stock Exchange of the Country making a count of 136 firms out of which only 07 firms dropped. All other sectors are relatively small as compared to the textiles but are given fair representation in the sample. However, a total of 330 companies made their place in the sample out of 369 non-financial firms listed on PSX. We divided the primary sample into further two sub-samples based on size as Detthamronga et al., (2017). We calculated the median value of assets and segregated the data based on it. Firms having assets excess of the median value are placed as large firms and others as small. Resultantly, placed 180 firms in Panel B and other 150 firms in Panel C. 


\section{Measurement of Variables}

Dependent Variable

This study aims at investigating the impact of growth led financing on insolvency risk. Therefore, insolvency risk treated as a dependent variable for Pakistan based non-financial listed firms. We used an accounting-based insolvency risk measure described as the Z-score model (Roy, 1952). The proxy Z-score used by the previous researchers like Laeven \& Levine (2009), Houston, Lin, Lin, \& Ma (2010), and Akbar, Kharabsheh, Poletti-Hughes \& Shah (2017). A higher value of the Z-score indicates that a firm has low insolvency risk and vice versa. Z-score risk calculated through the following equation:

$$
\text { Insolvency risk }=1 /[(R O A+C A R) /(S . D R O A)]
$$

Where, ROA represents the return on assets of all sample firms, CAR refers to the capital asset ratio, which is an output of division between total equity and total assets. Total equity also includes reserves both capital and revenue and even any surplus on revaluation of assets along with book value of shares as represented by SBP in financial statement analysis of non-financial firms. The notation S.D ROA stands for the standard deviation of return on assets. For this purpose, we used the return on assets of five years before the study period in this study. Pathan (2009), took the inverse of $\mathrm{Z}$-score to calculate insolvency risk and reported that higher Z-score refers to the level of higher firm-level solvency.

\section{Independent Variable}

As already discussed, this study focus on the impact of growth opportunities on the dependent variable, so, we treat them as the independent variable. There are several proxies used over the years for the measurement of growth, but we have preferred a more endogenous proxy that focuses on the assets of the firm in this study. An asset growth index calculated as in Bei \& Wijewardana (2012), Peng (2015) and Cooper, Gulen, \& Schill (2008) with the formula given below;

Growth Opportunities $=\left(\right.$ Assets $_{\mathrm{t}} /$ Assets $\left._{\mathrm{t}-1}\right)-1$

\section{Mediating Variable}

In this study, we have analyzed the impact of growth driven financing decisions on the insolvency risk of listed firms. Therefore, we want to examine the mediating role of financing decisions on the relationship between growth opportunities and insolvency risk. Financing decisions have two aspects of this study. One refers to the 
contribution of debt and equity in the capital structure of a company. The proxy for capital structure is 'Debt Ratio' (DR) which is calculated by dividing long term debt to total assets, similar to the one used by Heyman, Deloof and Ooghe, (2008), Sheikh and Wang (2012), Vakilifard, Gerayli, Yanesari and Ma'atoofi (2011), and Ibrahim and Lau (2019). The second part of the financing decision is 'Debt Maturity Ratio' (DMR), which is measured by the ratio between long term debt and total debt (Barclay \& Smith, 1995; Orman \& Bülent , 2015).

\section{Control Variable}

We have used three control variables in this study. The first one is profitability as higher profits are associated with higher risk levels, so we tend to control its effect, and we used basic earnings per share as a proxy for this variable. Tax saving is an essential element that motivates the managers to tilt their capital structure more towards debt. Therefore, we have considered tax separately as a control variable. We have also controlled the size effects by taking natural logged assets as our third control variable. The variable names, their notations, and methods of measurement explained in table 2.

Table 2: Operational Definition of Variables

\begin{tabular}{|l|l|l|}
\hline Variable & Notation & Measurement \\
\hline Insolvency Risk & IR(Insolvency Risk) & $1 /[(R O A+C A R) /(S . D R O A)]$ \\
\hline Growth Opportunities & GO(Growth Opportunities) & Rate of growth of the firm's total assets \\
\hline \multirow{3}{*}{ Financing Decision } & DR(Debt Ratio) & Total long term debt divided by total Assets \\
\cline { 2 - 3 } & DMR(Debt Maturity Ratio) & Long term Debt divided by total Debt \\
\hline \multirow{3}{*}{ Controls } & EPS(Profitability) & The ratio of net profit to shares outstanding \\
\cline { 2 - 3 } & lnTAX(Tax Expense) & Natural log of total expenses \\
\cline { 2 - 3 } & lnSIZE(Total Assets) & Natural log of total assets \\
\hline
\end{tabular}

\section{Research Methodology}

To detect the indirect and direct effects in mediation analysis, we will use Baron \& Kenny's (1986) approach considering the suggestions of Hsu, Wang \& Hsu (2012), and Guizani (Guizani, 2018). Baron \& Kenny's (1986) method involves the testing of relationships in the following steps:

1. Checking the impact of Independent Variable (IV) on the Mediator (M).

2. Testing the effect of the Independent Variable (IV) on the Dependent Variable (DV).

3. Checking the impact of both the Independent Variable (IV) and Mediator (M) on Dependent Variable (IV).

Hsu et al. (2012) and Guizani (2018), explained that four conditions must be met to conduct a mediation analysis. They said that there should be a significant impact 
of the independent variable on the dependent variable, then the independent variable must influence the mediator. Further, the mediator affects the dependent variable and finally analyzing the impact of the independent variable on the dependent variable after controlling the mediation effects in the same regression. We will follow the Baron and Kenny's (1986) approach comprising of three steps as the last step is a combination of the previous two conditions set out by Hsu et al. (2012), so, we don't need to regress dependent Variable on mediator separately. Moreover, three alternative scenarios may emerge as a result when we undergo these three steps. Firstly, there will be full mediation if the impact of independent variables no longer remains significant in the presence of the mediator. Secondly, there will be partial mediation if this impact remains substantial, but the coefficient values and level of significance fluctuates. If none of the above conditions are met, then there will be no mediation.

Above mentioned possible relationships are explained through the following functions.

\section{Step 1:}

Capital Structure $=f($ Growth Opportunities, Controls)

Debt Maturity $=f($ Growth Opportunities, Controls $)$

\section{Step 2:}

Insolvency Risk $=f($ Growth Opportunities, Controls $)$

\section{Step 3:}

Insolvency Risk=f(Growth Opportunities, Capital Structure, Controls)

Insolvency Risk=f(Growth Opportunities, Debt Maturity, Controls

The resultant regression equations can be written as follows:

$$
\begin{aligned}
& D R i, t=\alpha+\beta 1(G O i, t)+\beta 2(E P S i, t)+\beta 3(\operatorname{lnSIZEi}, t)+\beta 4(\ln T A X i, t)+ \\
& \varepsilon t
\end{aligned}
$$

$D M R i, t=\alpha+\beta 1(G O i, t)+\beta 2(E P S i, t)+\beta 3(\operatorname{lnSIZEi}, t)+\beta 4(\ln T A X i, t)+$ $\varepsilon t$

$$
I R i, t=\alpha+\beta 1(G O i, t)+\beta 2(E P S i, t)+\beta 3(\operatorname{lnSIZEi}, t)+\beta 4(\ln T A X i, t)+
$$
$\varepsilon t$

$$
\begin{aligned}
& I R i, t=\alpha+\beta 1(G O i, t)+\beta 2(D R i, t)+\beta 3(E P S i, t)+\beta 4(\operatorname{lnSIZEi}, t)+\beta 4(\ln T A X i, t)+ \\
& \varepsilon t
\end{aligned}
$$

$I R i, t=\alpha+\beta 1(G O i, t)+\beta 2(D M R i, t)+\beta 3(E P S i, t)+\beta 4(\operatorname{lnSIZEi}, t)+\beta 5(\ln T A X i, t)+$ $\varepsilon t$

Various diagnostics performed to assess the nature and suitability of our analysis. To cope with the multicollinearity, we use the variance inflation factor (VIF) analysis. Its critical value limit is ten, as stated by Studenmund (2006). A VIF value greater than 10, 
points towards the very high multicollinearity among the variables under consideration in the regression model. To detect serial correlation, we employed the Breusch Godfrey test. There are various ways to fix this problem, and one of them is to place the lagged value of the dependent variable among the explanatory variable. So, we used this approach wherever this issue detected in our models. We applied the Breusch Pagan/Cook Weisberg test to identify whether there exists any heterogeneity in our models. In the case of non-homoscedastic data series, the underlying assumption of constant standard errors is violated, and we need to fix this issue while performing OLS. If this problem is not countered then the resultant standard errors may (usually) be underestimated, and spurious coefficients may pollute your regression inferences. In the case of panel data that means cross-sections observed on different time intervals, one way to fix this problem is robust clustering (Cameron \& Miller, 2015). It also implies that in panel data, there may be correlated model errors within clusters but may be uncorrelated across groups, for example, panel observations for the individual persons, regions, or firms, as in our case. So, we used robust clustered standard errors in our linear regressions to estimate our results.

\section{Results and Discussion}

Table 3: Descriptive Statistics

\begin{tabular}{|c|c|c|c|c|c|}
\hline \multicolumn{6}{|c|}{ Total Firms Panel A } \\
\hline Variables & Observations & Mean & Std.Deviation & Minimum & Maximum \\
\hline IR & 1650 & 0.622 & 20.802 & -408.535 & 664.670 \\
\hline $\mathrm{GO}$ & 1650 & 0.092 & 0.472 & -0.971 & 12.140 \\
\hline DMR & 1650 & 0.270 & 0.218 & 0 & 0.998 \\
\hline DR & 1650 & 0.206 & 0.607 & 0 & 10.801 \\
\hline EPS & 1650 & 10.653 & 46.787 & -435.98 & 728.78 \\
\hline $\operatorname{lnSIZE}$ & 1650 & 14.985 & 1.991 & 7.044 & 20.256 \\
\hline $\operatorname{lnTAX}$ & 1650 & 16.414 & 0.401 & 0.693 & 17.937 \\
\hline \multicolumn{6}{|c|}{ Large Firms Panel B } \\
\hline IR & 900 & 0.177 & 15.283 & -408.535 & 121.695 \\
\hline GO & 900 & 0.103 & 0.416 & -.874 & 9.87657 \\
\hline DMR & 900 & 0.270 & 0.198 & 0 & 0.939 \\
\hline DR & 900 & 0.145 & 0.127 & 0 & 0.874 \\
\hline EPS & 900 & 20.002 & 58.282 & -435.98 & 728.78 \\
\hline $\operatorname{lnSIZE}$ & 900 & 16.341 & 1.169 & 14.255 & 20.256 \\
\hline $\operatorname{lnTAX}$ & 900 & 16.426 & 0.543 & 0.693 & 17.937 \\
\hline \multicolumn{6}{|c|}{ Small Firms Panel C } \\
\hline IR & 750 & 1.156 & 25.919 & -56.814 & 664.670 \\
\hline GO & 750 & 0.078 & 0.531 & -.971 & 12.140 \\
\hline DMR & 750 & 0.270 & 0.239 & 0 & 0.998 \\
\hline DR & 750 & 0.278 & 0.885 & 0 & 10.801 \\
\hline EPS & 750 & -0.566 & 22.607 & -215.83 & 255.12 \\
\hline $\operatorname{lnSIZE}$ & 750 & 13.358 & 1.495 & 7.044 & 15.540 \\
\hline $\operatorname{lnTAX}$ & 750 & 16.400 & 0.002 & 16.381 & 16.420 \\
\hline
\end{tabular}


The above table-3 represents the descriptive analysis for all the three panels under consideration in this study. We used insolvency risk as an explanatory variable in our study. The above table reports that the overall mean value for insolvency risk is 0.622. Small firms are riskier as compared to large firms with mean values of 1.156 and 0.177 , respectively. Small firms are also facing problems in growing their assets as they have the lowest growth rate in terms of beta value that equals 0.078 . It states that these firms face high risk without considerably taking advantage of the growth opportunities. It is interesting to note that all three samples have similar debt maturities of 0.27 , which explains the proportion of long term debt in their debt structure. However, the total debt ratio describes the scenario differently as small firms have more percentage of borrowed money in their capital structure as compared to large firms. The mean value of the debt ratio is 0.278 in small firms as compared to the 0.145 in large firms, which appears almost double in value. Similarly, large firms have earnings per share (EPS) of 20.02, but it is volatile, with a standard deviation of 58.28. Whereas, small firms represent the negative mean value of earnings per share, i.e., -0.566 . There is not much difference in the tax values as the mean value of logarithm tax expenses is around 16.4 in the three samples under consideration.

Table 4: Correlations and Variance Inflation Factors

\begin{tabular}{|l|r|r|r|r|r|r|r|r|}
\hline & \multicolumn{1}{|c|}{ IR } & GO & DMR & DR & EPS & lnSIZE & lnTAX & VIF \\
\hline IR & 1 & & & & & & & \\
\hline GO & -0.041 & 1 & & & & & & 1.02 \\
\hline DMR & 0.027 & 0.094 & 1 & & & & & 1.21 \\
\hline DR & -0.002 & -0.03 & 0.372 & 1 & & & & 1.26 \\
\hline EPS & 0.007 & 0.053 & -0.034 & -0.05 & 1 & & & 1.04 \\
\hline lnSIZE & 0.006 & 0.031 & 0.055 & -0.234 & 0.186 & 1 & & 1.12 \\
\hline lnTAX & 0 & 0.008 & 0.01 & -0.007 & 0.027 & 0.034 & 1 & 1 \\
\hline
\end{tabular}

Table 4 represents the correlation coefficients of all variables in the overall sample with 1650 number of observations. We found that the value of correlation coefficients among all variables is below 0.50 , so there can be no issue of multicollinearity. However, to further investigate this issue, we employed the variance inflation factor (VIF). The values for VIF analysis are much lower than the critical value, which indicates that there is no multicollinearity among the variables. 
Table 5: Regression Results for Panel-A

\begin{tabular}{|l|c|c|c|c|c|}
\hline \multicolumn{1}{|c|}{ Variables } & $\begin{array}{c}\text { Model 1 } \\
\text { (IR) }\end{array}$ & $\begin{array}{c}\text { Model 2 } \\
\text { (DMR) }\end{array}$ & $\begin{array}{c}\text { Model 3 } \\
(\mathrm{IR})\end{array}$ & $\begin{array}{c}\text { Model 4 } \\
\text { (DR) }\end{array}$ & $\begin{array}{c}\text { Model 5 } \\
\text { (IR) }\end{array}$ \\
\hline GO & $-1.865^{*}$ & $0.025^{* *}$ & -1.999 & -0.034 & -1.867 \\
\hline DMR & & & $3.057^{* *}$ & & \\
\hline DR & & & & & -0.076 \\
\hline L1.DMR & & $0.818^{* * *}$ & & & \\
\hline L1.DR & & & & $0.982^{* * *}$ & \\
\hline EPS & 0.003 & 000 & 0.004 & 000 & 0.003 \\
\hline lnSIZE & 0.065 & $0.004^{* *}$ & 0.044 & $0.003^{* * *}$ & 0.060 \\
\hline lnTAX & -0.024 & -0.0001 & -0.041 & 0.001 & -0.024 \\
\hline R-square & 0.0019 & 0.7130 & 0.0029 & 0.959 & 0.0019 \\
\hline Breusch Godfrey & 1.008 & $790.619^{* * *}$ & 1.124 & $985.007^{* * *}$ & 1.049 \\
\hline Breusch Pagan/ Cook Weisberg & $12.02^{* * *}$ & $25.28^{* * *}$ & $7.31^{* * *}$ & $7111^{* * *}$ & $60.78^{* * *}$ \\
\hline
\end{tabular}

Note: Coefficients followed by $*$ are significant at $10 \%$, by $* *$ are significant at $5 \%$, and $* * *$ are significant at $1 \%$.

The regression results for Panel- A reported in table-5. Model 1 shows the negative but insignificant impact of growth opportunities on insolvency risk with a coefficient of -1.865 , which indicates an insignificant direct relationship among these variables. However, in model 2, growth opportunities have a positive and significant impact on the debt maturity ratio at a $5 \%$ level of significance with a beta coefficient of 0.025. Logarithmic value of size also has substantial implications for debt maturity ratio which indicates that the increase in assets causes a tendency to obtain long term debt. It supports the argument that a firm with more assets can be in a better position to use them as collateral to get loans. Mediation effects tested through model 3 for debt maturity ratio, which once again proposes an insignificant impact of growth opportunities on insolvency risk, but debt maturity has a positive effect on the insolvency ratio with a beta coefficient of 3.057 at $5 \%$ significance level. Therefore, it can be inferred that direct impact is insignificant, whereas, growth opportunities affect insolvency through debt maturity structure. In this table, model 4 reports the insignificant negative effect of growth opportunities on debt ratio with a -0.034 beta coefficient. Similarly, the relationship remains insignificant for growth opportunities and insolvency risk in model 5 and also for debt ratio and insolvency risk, which is designed to capture the mediating effects of capital structure. The heterogeneity problems were prevalent in all the five models controlled through robust clustering, and serial correlation detected in models $2 \& 4$. It was dealt with by using lagged variables of the dependent variables. 
Table 6: Regression Results for Panel-B

\begin{tabular}{|l|c|c|c|c|c|}
\hline \multicolumn{1}{|c|}{ Variables } & $\begin{array}{c}\text { Model 1 } \\
\text { (IR) }\end{array}$ & $\begin{array}{c}\text { Model 2 } \\
\text { (DMR) }\end{array}$ & $\begin{array}{c}\text { Model 3 } \\
(\mathrm{IR})\end{array}$ & $\begin{array}{c}\text { Model 4 } \\
\text { (DR) }\end{array}$ & $\begin{array}{c}\text { Model 5 } \\
(\mathrm{IR})\end{array}$ \\
\hline GO & $-0.475^{*}$ & $0.033^{* *}$ & $-0.710^{* *}$ & -0.024 & -0.555 \\
\hline DMR & & & $4.824^{* *}$ & & \\
\hline DR & & & & & 5.871 \\
\hline L1.DMR & & $0.869^{* * *}$ & & & \\
\hline L1.DR & & & & $0.881^{* * *}$ & \\
\hline EPS & $0.005^{*}$ & $-0.0001^{* *}$ & $0.006^{*}$ & $-0.0001^{* *}$ & $0.007^{*}$ \\
\hline lnSIZE & 0.332 & 0.0044 & 0.216 & $0.003^{* *}$ & 0.232 \\
\hline lnTAX & -0.008 & -0.0004 & 0.052 & 0.0001 & 0.023 \\
\hline R-square & 0.0012 & 0.7974 & 0.0050 & 0.8190 & 0.0035 \\
\hline Breusch Godfrey & 1.148 & $492.996^{* * *}$ & 1.469 & $494.200^{* * *}$ & 1.336 \\
\hline Breusch Pagan/ Cook Weisberg & $259.67 * * *$ & 0.450 & $363.64^{* * *}$ & $11.310^{* * *}$ & $461.50^{* * *}$ \\
\hline
\end{tabular}

Note: Coefficients followed by $*$ are significant at $10 \%$, by $* *$ are significant at $5 \%$, and $* * *$ are significant at $1 \%$.

Table-6 represents the regression results for large firms indicated as Panel-B. This table reports an insignificant and negative impact of growth opportunities on insolvency risk shown by the beta coefficient value of -0.475 , as indicated in model 1. Model 2 predicts the positive effect of growth opportunities on the debt maturity ratio at a $5 \%$ level of significance. The coefficient value for this relationship is 0.033 . The regression model 3 reports that by incorporating the debt maturity ratio as a mediator in the model, the impact of growth opportunities on insolvency risk has more strengthened as it's beta coefficient becomes -0.071 , and its p-value comes within a range of 5\%. This result strongly supports the role of the debt maturity ratio as an intervening variable between the relationship of growth and insolvency risk. Model 4 once again reports the insignificant negative impact of growth opportunities on debt ratio, and the relationship between growth opportunities and insolvency risk remains insignificant even after the inclusion of debt ratio as a mediator. The debt ratio has a positive but also insignificant impact on insolvency risk as reported in model 5 results. Once again, heterogeneity observed for all models except model 2 . The case of serial correlation was similar to that of the overall sample in which it was detected for model $2 \& 4$. The same procedure is applied to address this issue for the Panel-B. 
Table 7: Regression Results for Panel-C

\begin{tabular}{|l|c|c|c|c|c|}
\hline \multicolumn{1}{|c|}{ Variables } & $\begin{array}{c}\text { Model 1 } \\
\text { (IR) }\end{array}$ & $\begin{array}{c}\text { Model 2 } \\
(\mathrm{DMR})\end{array}$ & $\begin{array}{c}\text { Model 3 } \\
(\mathrm{IR})\end{array}$ & $\begin{array}{c}\text { Model 4 } \\
\text { (DR) }\end{array}$ & $\begin{array}{c}\text { Model 5 } \\
\text { (IR) }\end{array}$ \\
\hline GO & $-2.904^{* *}$ & $0.038^{* * *}$ & $-2.951^{* *}$ & -0.064 & $-2.903^{* *}$ \\
\hline DMR & & & 1.163 & & \\
\hline DR & & & & & 0.024 \\
\hline L1.dmr & & $0.651^{* * *}$ & & & \\
\hline L1.dr & & & & $0.737^{* * *}$ & \\
\hline EPS & $0.0191^{* * *}$ & $-0.005^{* * *}$ & $0.0185^{* * *}$ & 0.0001 & $0.019^{* * *}$ \\
\hline InSIZE & 0.804 & -0.0002 & 0.794 & $0.088^{* *}$ & 0.809 \\
\hline lnTAX & -152.379 & -2.429 & -143.234 & 3.881 & -152.443 \\
\hline R-square & 0.0056 & 0.4358 & 0.0057 & 0.6206 & 0.0056 \\
\hline Breusch Godfrey & 0.322 & $317.381^{* * *}$ & 0.329 & $460.985^{* * * *}$ & 0.323 \\
\hline Breusch Pagan/ Cook Weisberg & $49.75^{* * *}$ & $6.72^{* * *}$ & $56.35^{* * *}$ & $3283.39^{* * *}$ & $49.89 * * *$ \\
\hline
\end{tabular}

Note: Coefficients followed by $*$ are significant at $10 \%$, by $* *$ are significant at $5 \%$, and $* * *$ are significant at $1 \%$.

The regression results for small firms represented by Panel-B reported in table-7. Model 1 indicates a significant negative impact of growth opportunities on insolvency risk with a coefficient value of -2.904 . Growth opportunities also significantly influence the debt maturity decision in small firms. The beta coefficient for this relationship is 0.038 at a $1 \%$ level of significance, as given in the column headed by model 2 . Model 3 used to analyze the intervening effect of debt maturity shows that there is minimal variation in the beta coefficient of growth opportunities with a value of -2.951 at a p-value of less than 5\%. The impact of the debt maturity ratio is positive but insignificant in this model, with a coefficient valuing 1.163. The effect of growth opportunities on overall debt usage is negative and negligible, with a beta value of -0.064 . Model 5 also confirms a similar situation as that of the other two panels (A $\& \mathrm{~B})$ for the debt ratio. The role of the debt ratio as a mediator is non-existent as the impact of the independent variable is unchanged, and also the influence of the mediator on insolvency risk is insignificant but positive with a beta coefficient of 0.024 Results regarding heterogeneity are also consistent as to previous panels, and serial correlation also found in models $2 \& 4$.

Table 8: Sobel's Mediation Analysis

\begin{tabular}{|l|l|c|c|c|}
\hline \multicolumn{2}{|c|}{ Panel-A } & Panel-B & Panel-C \\
\hline \multirow{2}{*}{ DMR } & Sobel's t-stat & $1.494^{*}$ & $1.681^{* *}$ & 0.776 \\
\cline { 2 - 5 } & P-value & 0.067 & 0.046 & 0.218 \\
\hline \multirow{2}{*}{ DR } & Sobel's t-stat & 0.858 & 1.110 & 0.109 \\
\cline { 2 - 5 } & P-value & 0.195 & 0.133 & 0.456 \\
\hline
\end{tabular}

Note: Coefficients followed by * are significant at $10 \%$, by $* *$ are significant at $5 \%$, and $* * *$ are significant at $1 \%$. 
We notice that Sobel's test for the overall sample and large firms is significant at $10 \%$ and 5\%, respectively, as shown in table- 8 for Panel A \& B. Sobel's t-statistics for all firms is 1.494 with a p-value of 0.067 . Similarly, t-statistics for large firms is 1.681 and a p-value of 0.046 . However, an insignificant $t$-statistics value reported by Sobel's test for small firms. Therefore, the results suggest that the debt maturity ratio has a partial mediation effect on the relationship between growth opportunities and insolvency risk. As for, the debt ratio is concerned, no mediation effects detected for all the three panels used in this study. The impact of growth opportunities on insolvency risk is negative in all of the three samples, as reported by previous studies like (AlNajjar \& Riahi-Belkaoui, 2001; Akbar, Akbar , Tang, \& Qureshi, 2019; Shin \& Stulz, 2000). The impact of growth opportunities on the debt maturity ratio is found to be positive and significant in all three samples, similar to (Ibrahim \& Lau, 2019; Handoo \& Sharma, 2014). It explains that more preference is given to long term debt in comparison to the short term debt. It validates the agency cost theory and negates the information asymmetry hypothesis. It is similar to the proposition made by Myers (1977). However, the effects of growth opportunities on capital structure are negative, as mentioned in studies, for example, (Padrón, Apolinario, Santana, Martel, \& Sales, 2005; Karpavičius \& Yu, 2019) but insignificant. This negative association of growth with leverage negates the pecking order theory as firms rely more on equity in their capital structure. Debt maturity influenced insolvency risk positively, and it was significant for panels A \& B but insignificant for panel-C. Whereas, the impact of capital structure on insolvency risk represented by debt ratio is negative in the case of panel A similar to (Dierker, Lee, \& Seo, 2019) but positive for Panel B \& C as in (Bhagat, Bolton, \& Lu, 2015). However, this relationship is insignificant in all three cases, as also reported by (Chung, Na, \& Smith, 2013).

\section{Conclusion and Future Implications}

This study focus on analyzing the mediating role of financing decisions on the relationship between growth opportunities and insolvency risk in Pakistani listed non-financial firms. By using Baron \& Kenny's (1986) approach, we tried to capture the intervening effects of capital structure and debt maturity ratio for a sample of 330 firms using annual data from 2013 to 2017. Financing decisions comprised of two major areas including the decision regarding capital structure and choice regarding debt maturity. The results prove a negative impact of growth opportunities on insolvency risk. The effect of growth opportunities on the debt maturity ratio is also found positive but tested negative for capital structure denoted by debt ratio. This situation means that firms play safely in case of availing growth opportunities and tend to get long term loans to satisfy their financial needs and avoid rollover risk. Conservative firms also tend to reduce the proportion of debt in their capital structure, and hence, 
a negative association between growth and leverage ratio exists, which means these firms relied more on equity as compared to the debt. The impact of the debt maturity ratio showed a positive effect on insolvency risk, but in the case of capital structure, this relationship is negative. This situation explains that firms are unable to take advantage of the short term loan instead rely on the long term, which also is causing much risk in the listed firms. The negative association of leverage ratio with insolvency risk also indicates more reliance on equity than debt. We divided the overall sample into small and large firms on the basis median value of assets. The role of debt maturity ratio (DMR) was proved in the case of the sample of overall firms and large firms, whereas no such character detected when capital structure decisions used as a mediator. So, a partial mediation is established as further analyzed through Sobel's test on the part of financing decisions.

This study has multifaceted implications not only for academic users but also for managerial uses. It describes the importance of financing decisions, which, if not appropriately taken, can lead to higher insolvency risk while executing the growth opportunities chosen. Hence, management needs to take necessary care while making these decisions. The corporate debt structure is of equally great importance along with corporate structure decisions while implementing the financial policy of a company. Whereas prior literature mostly focuses on the importance of debt/equity structure, and due emphasis is not given to debt maturity structure. This research sheds light on this issue and that too in a mediating framework. Moreover, this analysis made on small and large companies as well. In large companies, the connectedness of financing decisions is quite evident, whereas small companies need to readdress this issue as they are riskier. So, it turns out to be very crucial for managers of small companies to align the firm's resources in a way that may increase firm value by utilizing the available growth opportunities without indulging in unmanageable insolvency risk. Further, it is suggested that this analysis may be extended by using different samples and employing more independent variables that may include corporate board attributes like board composition, board structure, ownership structure, and personal characteristics of the board members.

\section{Acknowledgement}

Funding: The study was funded by Major Research Project of Philosophy and Social Science in Colleges and Universities of Jiangsu Province (No. 2018SJZDA006) and Research Project of The Social Science Foundation of Jiangsu Province (No. 18GLB012) 


\section{REFERENCES}

Abor, J., \& Biekpe, N. (2009). How do we expalin the capital structur of SMEs in sub-Saharan Africa? Evidence from Ghana. Journal of Economic Studies, 36(1), 83-97.

Acharya, V., Gale, D., \& Yorulmazer, T. (2009). Rollover risk and market freezes. Working paper, NYU.

Ahsan, T., Wang, M., \& Qureshi, M. A. (2016). Firm, industry, and country level determinants of capital structure: Evidence from Pakistan. South Asian Journal of Global Business Research, $5(3), 362-384$.

Akbar, A., Akbar , M., Tang, W., \& Qureshi, M. A. (2019). Is Bankruptcy Risk Tied to Corporate Life-Cycle? Evidence from Pakistan. Sustainability, 11(678), 1-22. doi:10.3390/su11030678

Akbar, S., Karabsheh, B., Poletti-Hughes, J., \& Shah, S. Z. (2017). Board structure and corporate risk taking in the UK financial sector. International Review of Financial Analysis, 50, 101-110.

Akerlof, G. A. (1970). The market of "lemons": Quality and the market mechanism. Quarterly Journal of Economics, 84, 488-500.

Alipour, M., Mohammadi, M. S., \& Derakhshan, H. (2015). Determinants of capital structure: An empirical study of firms in Iran. International Journal of Law and Management, 57(1), 53-83.

Almeida, H., Campello, M., \& Weisbach, M. S. (2004). The cash flow sensitivity of cash. Journal of Finance, 59(4), 1777-1804.

AlNajjar, F. K., \& Riahi-Belkaoui, A. (2001). Empirical Validation of a General Model of Growth Opportunities. Managerial Finance, 27(3), 72-90.

Alonso, P., Lopez, I. F., \& Rodriguez, S. J. (2005). Financial decisions and growth opportunities: a Spanish frm's panel data analysis . Applied Financial Economics, 15, 391-407.

Amaral, M. (2008). Examine relationship between firm risk and firm growth. The accounting review, $180,54-65$.

Anderson, C. W., \& Garcia-Feijo, L. (2006). Empirical evidence on capital investment, growth options, and security returns. The Journal of Finance, 61, 171-194.

Autio, E., Sapienza, H. J., \& Almeida, J. G. (2000). Effects of age at entry, knowledge intensity, and imitability on international growth. Academy of Management Journal, 43, 909-924.

Baral, K. J. (2004). Determinants of capital structure: A case study of listed companies of Nepal. Journal of Nepalese Business Studies, 1(1), 1-13.

Barclay, M. J., \& Smith, C. W. (1995). The maturity structure of corporate debt. Journal of Finance, 50(2), 609-631.

Barnea, A., Haugen, R., \& Senbet, L. (1980). A rationale for debt maturity structure an call provisions in the agency theoretic framework. Journal of Finance, 35, 1223-1234.

Baron, R. M., \& Kenny, D. A. (1986). The moderator-mediator variable distinction in social psychological research: conceptual, strategic, and statistical considerations. ournal of Personality and Social Psychology, 51(6), 1173-1182.

Baum, C. F., Caglayan, M., Stephan, A., \& Talavera , O. (2008). Talavera Uncertainty determinants of corporate liquidity. Economic Modelling, 25(5), 833-849.

Beaver, W., Kettler, P., \& Scholes, M. (1970). The Association Between Market Determined and Accounting Determined Risk Measures. The Accounting Review, 45(4), 654-682.

Bei, Z., \& Wijewardana, W. P. (2012). Financial leverage, firm growth and financial strength in the listed companies in Sri Lanka. Procedia - Social and Behavioral Sciences, 40, 709-715.

Berk, J. B., Green, R. C., \& Naik, V. (1999). Optimal investment, growth options, and security returns. The Journal of Finance, 54, 1553-1607.

Bhagat, S., Bolton, B., \& Lu, J. (2015). Size, Leverage, and Risk-taking of Financial Institutions. Journal of Banking \& Finance, 59, 520-537. 
Billet, M. T., King, T. D., \& Mauer, D. C. (2007). Growth opportunities and the choice of leverage, debt maturity, and covenants. The Journal of Finance, 62(2), 697-730.

Bradley, M., Jarrel, G. A., \& Kim , E. H. (1984). On the existence of an optimal capital structure: theory and evidence. Journal of Finance, 39(3), 857-878.

Brealey, R. A., \& Myers, S. (1981). Principles of Corporate Finance. New York: Tata McGraw-Hill.

Brealey, R. A., Myers, S. C., \& Allen, F. (2008). Principles of Corporate Finance (9th ed.). Singapore: McGraw-Hill/Irwin.

Brunnermeier, M., \& Pedersen, L. (2009). Market liquidity and funding liquidity. Review of Financial Studies, 22, 2201-2238.

Cameron, C., \& Miller, D. L. (2015). A Practitioner's Guide to Cluster-Robust Inference. Journal of Human Resources, 50, 317-372.

Cao, C., Simin, T., \& Zhao, J. (2008). Can growth options explain the trend in idiosyncratic risk? The Review of Financial Studies, 21, 2599-2633.

Carey, M., \& Rosen, R. J. (2001). Public debt as a punching bag: An agency model of the mix of public and private debt.

Castanias, R. (1983). Bankruptcy risk and optimal capital structure. Journal of Finance, 38(5), 16171635.

Chaplinsky, S., \& Niehaus, G. (1990). The Tax and Distributional Effects of Leveraged ESOPs. Financial Management, 19(1), 29-38.

Chemmanur, T., \& Fulghieri, P. (1994). Reputation, renegotiation, and the choice between bank loans and publicly traded debt. Review of Financial Studies, 7(3), 475-506.

Chen, H. (2010). Macroeconomic conditions and the puzzles of credit spreads and capital structure. Journal of Finance, 65(6), 2171-2212.

Chen, L., \& Zhao, X. (2006). On the relation between the market-to-book ratio, growth opportunity, and leverage ratio. Finance Research Letters, 3(4), 253-266.

Chu, P. Y., \& Chiou, S. F. (1992). The determinants of corporate capital structure choice: Taiwan evidence. Journal of Management Science, 9(2), 159-177.

Chung, H. C. (1989). Debt and risk: a technical note. Journal of Business and Accounting, 16(5), 719727.

Chung, Y. P., Na, H. S., \& Smith, R. (2013). How important is capital structure policy to firm survival? Journal of Corporate Finance, 22, 83-103.

Cooper, M. J., Gulen, H., \& Schill, M. J. (2008). Asset growth and the cross-section of stock returns. The Journal of Finance, 63, 1609-1651.

Cuñat, V. (1999). Determinantes del plazo de endeudamiento de las empresas españolas. Investigaciones Económicas, 23(3), 351-392.

Danbolt, J., Hirst, I., \& Jones, E. (2002). Measuring growth opportunities. Applied Financial Economics, 12, 203-212.

Detthamronga, U., Chancharata, N., \& Vithessonthi, C. (2017). Corporate governance, capital structure and firm performance: Evidence from Thailand. Research in International Business and Finance, 42, 689-709.

Diamond, D. W., \& He, Z. (2014). A theory of debt maturity: the long and short of debt overhang. The Journal of Finance, 69(2), 719-762.

Diamonds, D. (1991). Debt maturity structure and liquidity risk. Quarterly Journal of Economics, 106, 709-737.

Dierker, M., Lee, I., \& Seo, S. W. (2019). Risk changes and external financing activities: tests of the dynamic trade-off theory of capital structure. Journal of Empirical Finance. doi:https://doi. org/10.1016/j.jempfin.2019.03.004

Dudley, E. (2012). Capital structure and large investment projects. Journal of Corporate Finance, 18(5), 1168-1192. 
Durinck, E., Laveren, E., \& Lybaert, N. (1997). The impact of sales growth above a sustainable level on the financing choice of Belgian Industrial SME's. Working Paper 1997014, UFSIA, Antwerpen.

Elgers, P. T., \& Murray, D. (1982). The impact of the choice of market index on the empirical evaluation of accounting risk measures. The Accounting Review, 57(2), 358-375.

Fewings, D. R. (1975). The impact of corporate growth on the risk of common stocks. Journal of finance, 30, 525-531.

Flannery, M. (1986). Asymmetric information and risky debt maturity choice. Journal of Finance, 41(1), 19-37.

Frank, M. Z., \& Goyal, V. K. (2003). Testing the pecking order theory of capital structure. Journal of Financial Economics, 67, 217-248.

Frank, M.Z., \& Goyal, V. K. (2009). Capital structure decisions: Which factors are reliably important? Financial Management, 38, 1-37.

Fu, F. (2010). Overinvestment and Operating Performance of SEO Firms. Financial Management, 39(1), 249-272.

Gertler, M., \& Hubbard, R. G. (1993). Corporate financial policy, taxation, and macroecononmic risk. Rand Journal of Economics, 24(2), 286-303.

Gomes, J., Kogan, L., \& Lu, Z. (2003). Gomes, Joao, Leonid Kogan, and Zhang Lu, 2003, Equilibrium cross section of returns. Journal of Political Economy, 111, 693-732.

Goyal, V. K., Lehn, K., \& Rcic, S. (2002). Growth opportunities and corporate debt policy: the case of the US defense industry. Journal of Financial Economics, 64, 35-59.

Gray, P., \& Johnson, J. (2011). The relationship between asset growth and the cross-section of stock returns. Journal of Banking \& Finance, 35(3), 670-680.

Guizani, M. (2018). The mediating effect of dividend payout on the relationship between internal governance and free cash flow", Corporate Governance. The International Journal of Business in Society, 18(4), 748-770.

Habib, A., \& Hasan, M. M. (2015). Firm life cycle, corporate risk taking and investor sentiment. Accounting and Finance, 57(2), 465-497.

Hamada, R. (1972). The Effect of the Firm's Capital Structure on the Systematic Risk of Common Stocks. The Journal of Finance, 27, 435-452.

Handoo, A., \& Sharma, K. (2014). A study on determinants of capital structure in India. IIMB Management Review, 26, 170-182.

He , Z., \& Xiong, W. (2009). Dynamic Debt Runs. Working paper 15482, University of Chicago.

Heckbarth, D., Miao, J., \& Morellec, E. (2006). Hackbarth, D., Miao, J., Morellec, E., 2006. Capital structure, credit risk, and macroeconomic conditions. Journal of Financial Economics, 82(3), 519-550.

Heshmati, H. (2001). On the growth of micro and small firms: evidence from Sweden. Small Business Economics, 17(3), 213-228.

Heyman, D., Deloof, M., \& Ooghe, H. (2008). The Financial Structure of Private Held Belgian Firms. Small Business Economics, 30, 301-313.

Honjo, Y., \& Harada, N. (2006). SME policy, financial structure and firm growth: evidence from Japan. Small Business Economics, 27(4), 289-300.

Houston, J. F., Lin, C., Lin, P., \& Ma, Y. (2010). Houston, J. F., Lin, C., Lin, P., and Ma, Y. (2010). Creditor rights, information sharing, and bank risk taking. Journal of Financial Economics, 96(3), 418-512.

Hsu, W. L., Wang, G. Y., \& Hsu, Y. P. (2012). Testing mediator and moderator effects of independent director on firm performance. International Journal of Mathematical Models and Methods in Applied Sciences, 6(5), 698-705.

Huyghebaert, N., \& Van de Gucht, L. (2007). The determinants of financial structure: New insights from business start-ups. European Financial Management, 13, 101-133. 
Ibrahim, H., \& Lau, T.-C. (2019). The determinants of financial leverage for surviving listed companies in Malaysia. International Journal of Business and Society, 20(1), 75-94.

Jaffe, J. F., \& Westerfield, R. (1987). Risk and the Optimal Debt Level. Modern Finance and Industrial Economics: Papers in Honour of I. Weston, Blackwell, Oxford, UK.

Jensen, M. C., \& Meckling, W. H. (1976). Theory of the firm: Managerial behavior, agency costs and ownership structure. Journal of Financial Economics, 3(4), 305-360.

Kale, J. R., Noe, T. H., \& Ramirez, G. G. (1991). The effect of business risk on corporate capital structure: theory and evidence. Journal of Finance, 46(5), 1693-1715.

Karpavičius, S., \& Yu, F. (2019). External growth opportunities and a firm's financing policy. International Review of Economics and Finance. doi:doi: https://doi.org/10.1016/j.iref.2019.04.007.

Kassim, A. M., Ishak, Z., \& Manaf, N. (2013). Board effectiveness and comapny performance: assessing the mediating role of capital structure decisions. International Journal of Business and Society, 14(2), 319-338.

Kester, W. (1984). Today's options for tomorrow's growth. Harvard Business Review, 62(2), 153-160.

Kim, B. (2011). Do Foreign Investors Encourage Value-Enhancing Corporate Risk Taking? Emerging Markets Finance and Trade, 47, 88-110.

Kim, W. S., \& Sorensen, E. H. (1986). Evidence on the impact of the agency costs of debt on corporate debt policy. Journal of Financial and Quantitative Analysis, 21(2), 131-144.

La Rocca, M. (2007). The influence of corporate governance on the relation between capital structure and value. Corporate Governance: The International Journal of Effective Board Performance, 7(3), 312-333.

Laeven, L., \& Levine, R. (2009). Bank governance, regulation and risk taking. Journal of Financial Economics, 93(2), 259-275.

Lang, L., Ofek, E., \& Stulz, R. M. (1996). Leverage, Investment, and Firm Growth. Journal of Financial Economics, 40, 3-29.

Leary, M. T., \& Roberts, M. R. (2014). Do peer firms affect corporate financial policy? Journal of Finance, 69, 139-178.

Leland, H. E. (1994b). Corporate debt value, bond covenants, and optimal capital structure. Journal of finance, 49, 1213-1252.

Leland, H. E., \& Pyle, D. H. (1977). Information asymmetric, financial structure, and financial intermediation. Journal of Finance, 32, 371-388.

Levy, A., \& Hennessy, C. (2007). Why does capital structure choice vary with macroeconomic conditions? Journal of Monetary Economics, 54(6), 1545-1564.

Lukason, O., \& Laitinen, E. K. (2016). Failure processes of old manufacturing firms in different European countries,. Investment Management and Financial Innovations, 13(2), 310-321.

Mateev, M., \& Anastasov, Y. (2010). Determinants of small and medium sized fast growing enterprises in central and eastern Europe: a panel data analysis. Financial Theory and Practice, 34(3), 269-295.

McConnell, J. J., \& Servaes, H. (1995). Equity Ownership and the Two Faces of Debt. Journal of Financial Economics, 39, 131-157.

Mellahi, K., \& Wilkinson, A. (2004). Organizational failure: A critique of recent research and a proposed integrative framework. International Journal of Management Reviews, 5(1), 21-41.

Modigliani, F., \& Miller, M. H. (1958). The cost of capital, corporate finance and the theory of investment. The American Economic Review, XLVIII(3), 261-297.

Morris, J. R. (1976). On Corporate Debt Maturity Strategies. Journal of Finance, 31, 29-37.

Morris, S., \& Shin , H. S. (2016). Illiquidity component of credit risk. International Economic Review, 57(4), 1135-1148.

Moyen, N. (2007). How big is the debt overhang problem? Journal of Economic Dynamics and Control, 31(2), 433-472. 
Myers, S. C. (1977). Determinants of corporate borrowing. Journal of Financial Economics, 5, 147-175. Myers, S. C. (1984). The capital structure puzzle. Journal of Finance, 39, 575-592.

Naseem, M. A., Lin, J., Rehman, R., Ahmad, M. I., \& Ali, R. (2019). Does capital structure mediate the link between CEO characteristics and firm performance? Management Decision. doi:https:// doi.org/10.1108/MD-05-2018-0594

Orman , C., \& Bülent, K. (2015). ,Structure of Debt Maturity across Firm Types. MPRA Paper No. 65958.

Padrón, Y. G., Apolinario, R. M., Santana, O. M., Martel, M. C., \& Sales, L. J. (2005). Determinant factors of leverage: An empirical analysis of Spanish corporations. The Journal of Risk Finance, 6(1), 60-68.

Pandey, I. M. (2001). Capital structure and the firm characteristics: evidence from an emerging market. IIMA Working Paper No. 2001-10-04. Retrieved from SSRN: http://ssrn.com/abstract $=300221$ or DOI: $10.2139 / \mathrm{ssrn} .300221$.

Parsons, C., \& Titman, S. (2007). Empirical Capital Structure: A Review. Foundations and Trends® in Finance, 3(1), 1-93.

Pathan, S. (2009). Strong boards, CEO power and bank risk-taking. Journal of Banking \& Finance, 33(7), 1340-1350.

Peng, X. (2015). Risk Taking and Firm Growth. RIETI Discussion Paper Series 15-E-061.

Ramli, N. A., \& Nartea, G. (2016). Mediation Effects of Firm Leverage in Malaysia: Partial Least Squares - Structural Equation Modeling. International Journal of Economics and Financial, 6(1), 301-307.

Ramli, N. A., Latan, H., \& Solovida, G. T. (2018). Determinants of Capital Structure and Firm Financial Performance - A PLS-SEM Approach: Evidence from Malaysia and Indonesia. Quarterly Review of Economics and Finance, 71, 148-160.

Ross, S. A. (1977). The determination of financial structure: The incentive signaling approach. Bell Journal of Economics, 8, 23-40.

Roy, A. D. (1952). Safety first and the holding of assets. Econometrica, 20(3), 431-449 Laeven, L., \& Levine, R. (2009). Bank governance, regulation and risk taking. Journal of Financial Economics, 93(2), 259-275.

Scherr, C. F., \& Hulburt, H. M. (2001). The Debt Maturity Structure of Small Firms. Journal of Financial Management, 30, 85-111.

Sheikh, N. A., \& Wang, Z. (2012). Nadeem Ahmed Sheikh and Zongjun Wang, Effects of corporate governance on capital structure: empirical evidence from Pakistan. Corporate Governance, 12(5), 629-641.

Shin, H.-H., \& Stulz, R. M. (2000). Shareholder Wealth and Firm Risk. Dice Center Working Paper No. 2000-19, 33.

Shleifer, A., \& Vishny, R. (2009). Unstable banking. Working paper 1523.

Skinner, D. J., \& Sloan, R. G. (2002). Earnings Surprises, Growth Expectations, and Stock Returns or Don't Let an Earnings Torpedo Sink Your Portfolio. Review of Accounting Studies, 7, 289-312.

Stohs, M., \& Mauer, D. (1996). The determinants of corporate debt maturity structure. Journal of Business, 69(3), 279-312.

Studenmund, A. H. (2006). Using Econometrics: A Practical Guide, Pearson New International Edition (6th ed.). Essex: Edinburgh Gate, Harlow.

Sun, J., Li, H., Huang, Q. -H., \& He, K. -Y. (2014). Predicting financial distress and corporate failure: A review from the state-of-the-art definitions, modeling, sampling, and featuring approaches. Knowledge-Based Systems, 57, 41-56.

Titman, S., \& Tsyplakov, S. (2007). A dynamic model of optimal capital structure. Review of Finance, $11,401-451$. 
Titman, S., \& Wessels, R. (1988). The determinants of capital structure choice. Journal of Finance, 43(1), 1-19.

Titman, S., Wei, J. C., \& Xie, F. (2004). Capital Investment \& Stock Returns. Journal of Financial and Quantitative Analysis, 39, 677-700.

Toy, N., Stonehill, A., Remmers, L., \& Wright, R. (1974). A comparative international study of growth, profitability, and risk as determinants of corporate debt ratios in the manufacturing sector. Journal of Financial and Quantitative Analysis, 9(5), 875-886.

Umrie, H. R., \& Yuliani. (2014). Ownership structure, innovation to firm value with the financing decision as mediation. Journal of Economics, Business, and Accountancy Ventura, 17(2), 245-258.

Vakilifard, H. R., Gerayli, M. S., Yanesari, A. M., \& Ma'atoofi, A. R. (2011). Effect of Corporate Governance on Capital Structure: Case of the Iranian Listed Firms. European Journal of Economics, Finance and Administrative Sciences, 35, 165-172.

Van Essen, M., Van Oosterhout, J. H., \& Carney, M. (2012). Corporate boards and the performance of Asian firms: A meta-analysis. Asia Pacific Journal of Management, 29(4), 873-905.

Wu, X., \& Yeung, C. K. (2012). Firm growth type and capital structure persistence. Journal of Banking and Finance, 36(12), 3427-3443.

Yang, W. (2005). Corporate Investment and Value Creation . Indiana University Bloomington. Working Paper Series. Retrieved from SSRN: http://ssrn.com/abstract=888324 or http://dx.doi. org/10.2139/ssrn.88832.

Yosha, O. (1995). Information disclosure costs and the choice of financing source. Journal of Financial Intermediation, 4, 3-20.

Zhang, X., Venus, J., \& Wang, Y. (2012). Family ownership and business expansion of small- and medium-sized Chinese family businesses: The mediating role of financing preference. Journal of Family Business Strategy, 3, 97-105. 